\title{
Dance with Critical Thinking and Creative Thinking in the Classroom
}

\author{
Kuan Chen Tsai \\ University of the Incarnate Word \\ Accepted: August 15, 2012 Published: September 21, 2012 \\ Doi:10.5296/jsr.v3i2.2323 \\ URL: http://dx.doi.org/10.5296/jsr.v3i2.2323
}

\begin{abstract}
This article examines the theoretical underpinnings of critical thinking and creative thinking in order to encourage educators to include two key thinking skills in their daily classrooms. It draws purposefully and selectively from research evidence and theory across the fields of education, psychology, and professional development to draw attention to the assentation that more structured and theoretically informed teachings of critical and creative thinking in education could be useful to student learning. First, definitions of critical and creative thinking are discussed. Then, some studies with the focus of critical and creative thinking are reviewed. Finally, some suggestions for the implementation of two thinking styles in the classrooms are provided.
\end{abstract}

Keywords: critical thinking, creative thinking, problem-based learning

\section{Introduction}

Dewey (1916) has identified that the purpose of education is rooted in the development of a continually growing democracy through the necessity of thinking critically. Paul (1990) maintained that "in education the whole is greater than the sum of the parts. We need to forge connections that shape the parts to form a coherent educational whole" (p. 232). In order to achieve this goal, we need to provide opportunities and incentives for students to teach them how, what, and why to think, with the appropriate curricula and instructions.

Mendelman (2007) noted that the importance of critical thinking has been recognized; however, in practice, this "lofty title is a gross misnomer... that the majority of the U.S. schools fail to teach critical thinking" (p. 300). Furthermore, the activities of promoting critical thinking have been curtailed in the daily classrooms because of the focus on the high-stakes standard testing movement (Law \& Kaufhold, 2009). In a similar vein, the power of creative thinking in classrooms is also underestimated (Beghetto \& Kaufman, 2010; Sternberg, 2010). Baldwin (2010) asserted that creative thinking is an important capacity because it will help students "draw upon their inner strengths and apply those strengths to the academic challenges they 
face" (p. 84).

The ability to be a critical and creative thinker is held as being particularly essential across health care professions, practitioners, education, and organisation (Mumford, Antes, Caughron, Connelly, \& Beeler, 2010; Phan, 2010; Smith, 2011; Tan, 2006). Gruenfeld (2010) argued that persons who think creatively also think critically. Sorensen (2010) has identified that the capacity of creative and critical thinking is especially imperative for the U.S. Army to develop leadership excellence. Baum and Newbill (2010) noted that creative and critical thinking play an essential role in the instructional design process. From the perspectives of philosophy for children, Weber (2011) followed the notion of German philosopher Friedrich Schiller and argued that through practicing play and imagination (creative thinking), children could embrace rational reflection (critical thinking).

In the education arena, Seymour, Kinn, and Sutherland (2003) supported the idea of integrating creative and critical thinking into nursing education in light of the potential benefits of research and clinical decision-making. In the U.K. the Qualifications and Curriculum Authority/Department for Education and Employment (1999) have suggested five important thinking skills that should be learned: information-processing skills, reasoning skills, inquiry skills, creative thinking skills, and evaluation skills. According to this proposition, it implies that two important thinking skills that students are required to learn in the education system are creative thinking and critical thinking.

This article examines the theoretical underpinnings of critical thinking and creative thinking in order to encourage educators to include two key thinking skills in their daily classrooms. It draws purposefully and selectively from research evidence and theory across the fields of education, psychology, and professional development to draw attention to the assertion that more structured and theoretically informed teachings of critical and creative thinking in education could be useful to student learning.

\section{The Constructions of Critical Thinking}

Paul (1990) defined critical thinking as "disciplined, self-directed thinking which exemplifies the perfections of thinking appropriate to a particular mode or domain of thought" (p. 51). Paul (1990) highlighted three important dimensions of critical thinking: the perfections of thought, the elements of thought, and the domains of thought. He argued that in order to attain the perfections of thought, one is required to formulate and assess several elements of thought (problems, purposes, assumptions, principles, evidence, interpretations, implications, and consequences). Furthermore, it is also necessary to cultivate this mode of thought, or "traits of mind" which include: intellectual humility, intellectual courage, intellectual empathy, integrity, intellectual perseverance, faith in reason, and intellectual sense of justice (p. 54). Scriven and Paul (1987) in their National Council for Excellence in Critical Thinking stated:

Critical thinking is the intellectually disciplined process of actively and skillfully 
conceptualizing, applying, analyzing, synthesizing, and/or evaluating information gathered from, or generated by, observation, experience, reflection, reasoning, or communication, as a guide to belief and action. In its exemplary form, it is based on universal intellectual values that transcend subject matter divisions: clarity, accuracy, precision, consistency, relevance, sound evidence, good reason, depth, breadth, and fairness.

The premise of critical thinking is grounded in an appropriate pedagogical method to learn to analyze and evaluate individual's thinking processes (Anderson-Meger, 2011). Smith (2011) has identified the nuances of the notion of critical thinking used in different contexts. For example, critical thinking is generally perceived as the outcome of learning, while critical analysis is more likely approached as an academic research study. A similar concept is critical reflection, which is described as students perceiving knowledge in their higher education experiences.

The promotion of critical thinking may be credited to Dewey (1933) who discussed this practice as "active, persistent, and careful consideration of any belief or supposed form of knowledge" (p. 9). Following this line, Mezirow (1991) theorized transformative education which is categorized into four stages: habitual action, understanding, reflection, and critical thinking. He viewed critical thinking as a higher dimension of reflective thinking with the purpose of meaningful understanding of oneself.

Phan (2010) maintained that critical thinking could serve as an imperative theoretical foundation that boosts students' motivation in teaching and learning. The main reason is that "critical thinking helps individuals to think and analyze critically about their own learning, and to strive and develop expertise in their areas of professionalism"(p. 284). In order to learn how to think critically in terms of problem solving, Wright (2002) recognized that "students need to have background information about it, criteria for judging the matter, knowledge of critical-thinking vocabulary, thinking strategies, and certain habits of mind" (p. 258). Specifically, at the heart of critical thinking, it is imperative to teach students to justify their answers "reasonably, effectively, carefully, and seriously" (p. 258).

Paul and Elder (2007) proposed five fundamental critical thinking concepts: (1) analyzing thought, (2) assessing thought, (3) analyzing questions by system, (4) developing prior questions, and (5) identifying domains within complex questions (p. 4). From the perspective of social work education, Anderson-Meger (2011) argued that critical thinking is important because of the fact that "solving ethical dilemmas, evaluating research findings, developing arguments, clarifying definitions and directions, and organizing and creating new knowledge are functions of social work practice that require critical thinking" (p. 18). Central to this process is the ability to "synthesize, compare, evaluate, and encourage the uprooting of deep held assumptions, values, and beliefs" (p. 19).

Paul and Elder (2007) also extended the concept of critical thinking and suggested the 
importance of Socratic questioning in teaching in order to deepen the power of critical thinking. Especially, "critical thinking provides the conceptual tools for understanding how the mind functions; Socratic questioning employs those tools in framing questions essential to the pursuit of meaning and truth" (pp. 2-3). Further, they recognized the goals of critical thinking and Socratic questioning are rooted in the systematic and disciplined line of reasoning:

The goal of critical thinking is to establish an additional level of thinking, a powerful inner voice of reason, that monitors, assesses, and reconstitutes - in a more rational direction - our thinking, feeling, and action. Socratic discussion cultivates that inner voice through an explicit focus on self-directed, disciplined questioning. (p. 3)

With regard to critical thinking in nursing education, Yildirim and Özsoy (2011) recognized the merits of critical thinking on positive academic success for students who took a critical thinking class. They finally suggested critical thinking could be a good tool for nurses to improve their theoretical knowledge, scenario studies, and practicing techniques. With the examination of the effects of critical thinking in a virtual learning environment, Saadé, Morin, and Thomas (2012) concluded that the use of critical thinking could foster interactivity in this unique environment. In addition, Molee, Henry, Sessa, and McKinney-Prupis (2010) discovered that the products of critical thinking could function as a beneficial tool to document and assess service-learning courses.

A correlational study conducted by McMahon (2009) showed a positive association between students who had higher computing skills and students who scored higher on critical thinking activities. In another study using an argument analysis test, Bensley, Crowe, Bernhardt, Buckner, and Allman (2010) found the explicit instruction of critical thinking skills is important in improving critical thinking skills in the regular psychology course. Based on empirical data, Phan (2010) concluded that the experience of critical thinking practice is a complex process that is influenced by various antecedents.

\section{The Features of Creative Thinking}

Campbell (1960) proposed a blind-variation-and-selective-retention theory of creative thinking, which is derived from observation of trial-and-error learning in animals and the theory of organic evolution, including: (a) a mnemonic representation of environment, (b) a mnemonic search or thought-trial process, (c) a thought-trial generating and changing process, (d) selective criteria, (e) a preservation or propagation process, and (f) a reality testing process in which the selected thought trials are checked (p. 397). Inspired by Darwin, Simonton (1999) extended Campbell's proposition and elaborated a comprehensive explanation from the standpoint of Darwinian theory on creativity. The main idea is to use Darwinian theories to facilitate the understanding of the prominent aspects of creative genius. Simonton (1999) underscored the influence of blind variations on creativity in terms of associative richness, mental imagery, intuitive cognition, intellect, personality, psychopathology, creative product, and culture and groups. 
Torrance (1988) viewed creativity in terms of "the process of sensing difficulties, problems, gaps information, missing elements, something askew; making guesses and formulating hypotheses about these deficiencies; evaluating and testing these guesses and hypotheses; possibly revising and retesting them; and finally communicating the results" (p. 43). Fasko (2006) claimed the function of creative thinking is to synthesize the information and then generate novel solutions. Weisberg (2006) stated that creative thinking is a "process underlying production of creative products" (p. 7).

Runco and Chand (1995) defined creative thinking as the thinking that "leads to original and adaptive ideas, solutions, or insights" (p. 244). They proposed a two-tier model of creative thinking, having two tiers with three components in the primary tier and two in a secondary tier. The primary components consist of problem finding processes, ideational processes, and judgmental processes. The second tier reflects knowledge and motivation. The first element of problem finding represents problem construction, problem formulation, problem expression, problem identification, and problem definition. The second component in the primary tier represents ideational processes, which includes ideational fluency, ideational originality, and ideational flexibility. Evaluative processes represent valuation and critical evaluation. Knowledge is in the second tier with two dimensions: declarative knowledge and procedural knowledge. The former represents factual knowledge while the latter represents know-how. Both types of knowledge can facilitate or inhibit creative thinking. Finally, both intrinsic and extrinsic motivation are also included in this model to explain that individuals only use their skills when motivated to do so. In addition, different components of this model interact with one another. The emphasis of interactions is to point out that in reality distinct stages do not exist; rather, the creative thinking process is an interactive or recursive interplay of different components suggested by this model.

Treffinger and Isaksen (2005) delineated that creative thinking includes two stages; first is the divergent phase of producing ideas, and then the critical convergent stage for evaluation. This creative thinking process consists of understanding the problem, generating ideas, and planning for action. In terms of understanding the problem, mess finding, data finding, and problem finding are three elements in this phase. Generating ideas is concerned with divergent thinking, elaboration of ideas, and convergent thinking. Finally, the planning for action is to develop and implement workable solutions and accept the findings.

In respect of creative thinking in business students, Driver (2001) employed several salient treatments that encourage creativity in the classroom. The results of the survey from the business students demonstrated their perceptions of classroom environment which positively encourages their creative behavior. Fontenot (1993) investigated the effects of the Creative Problem Solving model on business people. The main finding showed the experimental group had more fluency and flexibility in data finding and problem finding than the control group. Young Ju, Bain, and McCallum (2007) found that with explicit instructions of divergent thinking training on third culture children, they did improve originality and fluency in terms of 
problem-solving tasks. Through the implementation of curriculum that stresses active learning, exploration, self-evaluation, problem finding, and problem solving, Maker, Jo, and Muammar (2008) uncovered the students' performance of creative thinking increased within three consecutive years. In similar fashion, Ramey and Piper (1974) also found open classroom settings are favorable to development of creative thinking, compared to traditional classroom settings.

\section{Some Suggestions for Implementation of Creative Thinking and Critical Thinking}

Implied in critical thinking concepts and principles, Paul and Elder (2011) suggested 30 possible teaching strategies. They summarized those strategies in this guide: (1) let students know what they are in for; (2) design coverage so that students grasp the fundamental ideas intrinsic to the content; (3) spell out explicitly the intellectual standards you will be using in your grading; (4) focus on fundamental and powerful concepts with high generalizability; (5) present concepts, as far as possible, in the context of their use as functional tools for the solution of real problems and the analysis of significant issues; (6) keep the logic of the most basic concepts in the foreground, continually re-weaving new concepts into the basic ones; and (7) in general design all activities and assignments, including readings, so that students must think their way through them (p. 45).

Lyutykh (2009) argued that practicing critical thinking in the classroom should take social-cultural contexts into consideration. "CT [Critical Thinking] is a socio-cultural practice, not a discrete skill. To think critically is to engage in dialogue, to argue, to agree, to test limits, and to stretch boundaries"(p. 384). Because this socially bounded disposition shapes individual habits of mind, sometimes it is difficult for students to challenge the authority (the right answer). As a consequence, Lyutykh (2009) suggested that educators use multiple-perspective inquiry to highlight "the coexistence and juxtaposition of multiple, competing frames of reference" (p. 386). By doing so, it is possible to go beyond the normative perspective into a more specific understanding of "how particular socio-cultural practices and worldviews nest educational theory" (p. 387). Further, this approach serves as a vehicle to overcome and evaluate self biases in knowledge construction. Above all, as Smith (2011) noted, teaching critical thinking is for intellectual challenge

After examining 133 studies, Torrance (1972) found that the most effective training programs in terms of creative thinking include two important elements: cognitive and affective attributes that provide students opportunities to practice creative thinking. He then concluded "the most successful approaches seem to be those that involve both cognitive and emotional functioning, providing adequate structure and motivation, and give opportunities for involvement, practice, and interaction with teachers and other children" (p. 9). Csikszentmihalyi and Beattie (1979) also recognized the importance of cognitive and affective perspective on creativity.

Beghetto (2006) underscored the key role teachers play because "students' experiences within classrooms are greatly influenced by their perceptions of how teachers relate to them" (p. 449). 
He found the positive relationship between students' motivational beliefs and teachers' feedback on creative performance and concluded teachers should provide a supportive environment where students are willing to take risks for the sake of creative expression. Beghetto (2007) also suggested "rather than spend time seeking out some sure-fire technique for promoting student creativity, teachers might better spend time focusing their attention on how their everyday classroom policies, procedures, and practices support or thwart creative expression" (p. 108).

Myers and Torrance (1961) found some characteristics of teachers who are not supportive of creativity in the classroom: authoritarian, defensive, dominated by time, insensitive to students' intellectual and emotional needs, lacking in energy, preoccupied with their information-giving functions, intellectually inert, disinterested in promoting initiative and self-reliance in their students, preoccupied with disciplinary matters, unwillingness of teacher-learning compact (p. 159). Consequently, they proposed five principles for rewarding creative thinking in children: (1) treat questions with respect, (2) treat imaginative ideas with respect, (3) value students' ideas, (4) encourage practice-learning without the threat of evaluation, and (5) tie in evaluation with causes and consequences (p. 159).

Sternberg (2010) has pointed out "if we want to encourage creativity, we need to promote the creativity habit" (p. 397). As a result, he suggested that in order to successfully promote creativity in classrooms, teachers should role model creativity. Sternberg (2007) referred creativity as a habit which can be encouraged or discouraged. In so doing, he provided 12 keys for promoting the creativity habit in children: (a) redefine problems, (b) question and analyze assumptions, (c) do not assume that creative ideas sell themselves, (d) encourage idea generation, (e) recognize that knowledge is a double-edged sword and act accordingly, (f) encourage children to identify and surmount obstacles, (g) encourage sensible risk-taking, (h) encourage tolerance of ambiguity, (i) help children build self-efficacy, (j) help children find what they love to do, $(\mathrm{k})$ teach children the importance of delaying gratification, and (l) provide an environment that fosters creativity (pp. 8-20).

Hallman (1967) argued that creative teaching is the best approach to creative behavior of students. He provided some suggestions to the creative teacher: (1) self-initiated learning, (2) nonauthoritarian learning environment, (3) saturating students with information, imagery, and meanings, (4) creative thought process, (5) defer judgment, (6) promoting intellectual flexibility, (7) encouraging self-evaluation, (8) asking open-ended questions, (9) providing opportunities of craftsmanship, (10) facing frustration and failure, and (11) considering problems as a whole.

Problem-Based Leaning (PBL; Nilson, 2010) model could be a beneficial example to illustrate how teachers could bring creative thinking and critical thinking into the classrooms. There are two stages to complete the task. The first phase is the inventive creative stage of idea generation. The consequent phase is a critical assessment of idea evaluation. Creative thinking plays the major role in the first part of PBL and critical thinking takes the lead in the second 
part. Wright (2002) provided some considerations for teachers while designing problematic situations for critical thinking: (1) they require the students to make judgments; (2) the answers are meaningful to students; (3) the critical thinking tasks are embedded in the curriculum; and (4) the tasks are feasible. After designing suitable problems for students to investigate, teachers at first could ask students to identify the issues and redefine the problems. As Csikszentmihalyi and Beattie (1979) suggested, defining problems is an important stage of creativity. When students recognize the proposed problems, teachers could encourage them to come up with different possible solutions. At this phase, it is important to defer judgment. The goal is quantity not quality of ideas (Puccio \& Keller-Mathers, 2007). Finally, based on the possible solutions students generate, teachers then ask them to use critical perspectives to evaluate pros and cons of different ideas. The purpose is to optimize the best solution to the proposed problem. By using this suggested method, students could practice both critical and creative thinking and in turn transfer those two thinking strategies to their real life issues.

\section{Conclusions}

Lipman (1993) extended Dewey's (1933) theory of inquiry and concluded that good thinking is the key goal of education which includes two elements (critical and creative thinking) in interaction with one another. Most important, good thinking needs self-corrective practice. With regard to critical and creative thinking, Treffinger (1986) gave a fair statement: "neither divergent (creative) nor convergent (critical) thinking in itself is sufficient for promoting effective thinking and problem solving: both sets of skills must apparently be used in harmony" (p. 18). In addition, Clegg (2008) pointed to the interplay between critical and creative thinking and stated "critical assault on confining ideas, structures and even modes of "being" is fundamental to creativity. Creativity and critical faculties are intimately linked" (p. 221).

Paul (1990) reminded us that "all knowledge exists in and through critical thought" (p. 47). He also pointed out the fundamental problems in the educational process are that teachers put more weight on memorization and the fragmentation of curricula, thereby leading to a dearth of connection and depth within and between all subjects. As a consequence, critical and creative thinking could serve a unifying role that brings curriculum, instruction, and learning together. In the advancement of this discussion, it is believed that both creative thinking and critical thinking, as distinct disciplinary practices, interact intricately to contribute to students' knowledge and development. This notion could suggest that educators and learners should use various cognitive strategies to maximize learning outcomes and in turn result in better academic performance. Above all, in order to master both thinking skills, it needs time and efforts to practice, nurture, and reinforce over time.

\section{References}

Anderson-Meger, J. (2011). Critical thinking and E-learning in social work education. International Journal of Business, Humanities \& Technology, 1(2), 17-27. 


\section{I Macrothink}

Baldwin, A. Y. (2010). Creativity: A look outside the box in classrooms. In R. A. Beghetto \& J. C. Kaufman (Eds.), Nurturing creativity in the classroom (pp. 73-87). New York, NY: Cambridge University Press.

Baum, L. M., \& Newbill, P. L. (2010). Instructional design as critical and creative thinking: A journey through a Jamestown-Era native American village. TechTrends: Linking Research \& Practice to Improve Learning, 54(5), 27-37. doi:10.1007/s11528-010-0434-Z

Beghetto, R. A. (2006). Creative self-efficacy: Correlates in middle and secondary students. Creativity Research Journal, 18(4), 447-457. doi:10.1207/s15326934crj1804_4

Beghetto, R. A. (2007). Creativity research and the classroom: From pitfalls to potential. In A.G. Tan (Ed.), Creativity: A handbook for teachers (pp.101-114). Hackensack, NJ: World Scientific Publishing.

Beghetto, R. A., \& Kaufman, J. C. (2010). Broadening conceptions of creativity in the classroom. In R. A. Beghetto \& J. C. Kaufman (Eds.), Nurturing creativity in the classroom (pp. 191-205). New York, NY: Cambridge University Press.

Bensley, D., Crowe, D. S., Bernhardt, P., Buckner, C., \& Allman, A. L. (2010). Teaching and assessing critical thinking skills for argument analysis in psychology. Teaching of Psychology, 37(2), 91-96. doi:10.1080/00986281003626656

Campbell, D. T. (1960). Blind variation and selective retention in creative thought as in other knowledge processes. Psychological Review, 67(6), 380-400.

Clegg, P. (2008). Creativity and critical thinking in the globalised university. Innovations in Education \& Teaching International, 45(3), 219-226. doi:10.1080/14703290802175982

Csikszentmihalyi, M., \& Beattie, O. V. (1979). Life themes: A theoretical and empirical exploration of their origins and effects. Journal of Humanistic Psychology, 19(1), 45-63.

Dewey, J. (1916). Democracy and education: An introduction of philosophy of education. New York: The Macmillan.

Dewey, J. (1933). How we think. Chicago: Henry Regnery.

Driver, M. (2001). Fostering creativity in business education: Developing creative classroom environments to provide students with critical workplace competencies. Journal of Education for Business, 77(1), 28-34. 
Fasko, D. (2006). Creative thinking and reasoning: Can you have one without the other? In J. C. Kaufman \& J. Baer (Eds.), Creativity and reason in cognitive development (pp. 159-176). New York, NY: Cambridge University Press.

Fontenot, N. A. (1993). Effects of training in creativity and creative problem finding upon business people. Journal of Social Psychology, 133(1), 11-22.

Gruenfeld, E. (2010). Thinking creatively is thinking critically. New Directions for Youth Development, 2010(125), 71-83. doi:10.1002/yd.339

Hallman, R. J. (1967). Techniques of creative teaching. The journal of creative behavior, 1(3), 325-330.

Law, C., \& Kaufhold, J. A. (2009). An analysis of the use of critical thinking skills in reading and language arts instruction. Reading Improvement, 46(1), 29-34.

Lipman, M. (1993). Promoting better classroom thinking. Educational Psychology, 13(3/4), 291-304.

Lyutykh, E. (2009). Practicing critical thinking in an educational psychology classroom: Reflections from a cultural-historical perspective. Educational Studies, 45(4), 377-391. doi:10.1080/00131940903066263

Maker, C., Jo, S., \& Muammar, O. M. (2008). Development of creativity: The influence of varying levels of implementation of the DISCOVER curriculum model, a non-traditional pedagogical approach. Learning \& Individual Differences, 18(4), 402-417. doi:10.1016/j.lindif.2008.03.003

McMahon, G. (2009). Critical thinking and ICT integration in a Western Australian secondary school. Journal of Educational Technology \& Society, 12(4), 269-281.

Mendelman, L. (2007). Critical thinking and reading. Journal of Adolescent \& Adult Literacy, 51(4), 300-302.

Mezirow, J. (1991). Transformative dimensions of adult learning. San Francisco, CA: Jossey-Bass.

Molee, L. M., Henry, M. E., Sessa, V. I., \& McKinney-Prupis, E. R. (2010). Assessing learning in service-learning courses through critical reflection. Journal Of Experiential Education, 33(3), 239-257.

Mumford, M. D., Antes, A. L., Caughron, J. J., Connelly, S., \& Beeler, C. (2010). Cross-field differences in creative problem-solving skills: A comparison of health, biological, and 
social sciences. Creativity Research Journal, 22(1), 14-26. doi:10.1080/10400410903579510

Myers, R. E., \& Torrance, E. P. (1961). Can teachers encourage creative thinking? Educational Leadership, 19(1), 156-159.

Nilson, L. B. (2010). Teaching at its best: A research-based resource for college instructors (3rd ed.). San Francisco: Jossey-Bass.

Paul, R., \& Elder, L. (2007). The art of Socratic questioning. Dillon Beach, CA: Foundation for Critical Thinking Press.

Paul, R., \& Elder, L. (2011). How to improve student learning: 30 practical ideas. Dillon Beach, CA: Foundation for Critical Thinking Press.

Paul, R. W. (1990). Critical thinking: What every person needs to survive in a rapidly changing world. Rohnert Park, CA: Center for Critical Thinking and Moral Critique.

Phan, H. P. (2010). Critical thinking as a self-regulatory process component in teaching and learning. Psicothema, 22(2), 284-292.

Puccio, G. J., \& Keller-Mathers, S. (2007). Enhancing thinking and leadership skills through creative problem solving. In A.G. Tan (Ed.), Creativity: A handbook for teachers (pp. 281-301). Hackensack, NJ: World Scientific.

Qualifications and Curriculum Authority/Department for Education and Employment (1999). The national curriculum handbook for primary teachers in England. London, UK: DfEE/QCA.

Ramey, C. T., \& Piper, V. (1974). Creativity in open and traditional classrooms. Child Development, 45(2), 557-560. doi:10.1111/1467-8624.ep12156496

Runco, M. A., \& Chand, I. (1995). Cognition and creativity. Educational Psychology Review, 7(3), 243-267.

Saadé, R., Morin, D., \& Thomas, J. E. (2012). Critical thinking in E-learning environments. Computers in Human Behavior, 28(5), 1608-1617. doi:10.1016/j.chb.2012.03.025

Scriven, M., \& Paul, R. (1987). Critical thinking as defined by the National Council for Excellence in Critical Thinking. Retrieved from http://www.criticalthinking.org/pages/defining-critical-thinking/766

Seymour, B., Kinn, S., \& Sutherland, N. (2003). Valuing both critical and creative thinking in 
clinical practice: Narrowing the research-practice gap? Journal of Advanced Nursing, 42(3), 288-296. doi:10.1046/j.1365-2648.2003.02618.x

Simonton, D. K. (1999). Origins of genius: Darwinian perspectives on creativity. New York: Oxford University Press.

Smith, E. (2011). Teaching critical reflection. Teaching in Higher Education, 16(2), 211-223. doi:10.1080/13562517.2010.515022

Sorensen, G. (2010). Leadership beyond the battlefield. Public Manager, 39(4), 5-7. Sternberg, R. J. (2007). Creativity as a habit. In A.G. Tan (Ed.), Creativity: A handbook for teachers (pp. 3-26). Hackensack, NJ: World Scientific Publishing.

Sternberg, R. J. (2010). Teaching for creativity. In R. A. Beghetto \& J. C. Kaufman (Eds.), Nurturing creativity in the classroom (pp. 394-414). New York, NY: Cambridge University Press.

Tan, C. (2006). Creating thinking schools through 'Knowledge and Inquiry': The curriculum challenges for Singapore. Curriculum Journal, 17(1), 89-105. doi:10.1080/09585170600682640

Treffinger, D. J. (1986). Research on creativity. The Gifted Child Quarterly, 30(1), 15-19.

Treffinger, D. J., \& Isaksen, S. G. (2005). Creative problem solving: The history, development, and implications for gifted education and talent development. Gifted Child Quarterly, 49(4), 342-353.

Torrance, E. P. (1972). Can we teach children to think creatively? Journal of Creative Behavior, 6(2), 114-143.

Torrance, E. P. (1988). The nature of creativity as manifest in its test. In R. J. Sternberg (Ed.), The nature of creativity: Contemporary psychology perspectives (pp. 43-75). New York: Cambridge University Press.

Weber, B. (2011). Childhood, philosophy and play: Friedrich Schiller and the interface between reason, passion and sensation. Journal of Philosophy of Education, 45(2), 235-250. doi:10.1111/j.1467-9752.2011.00804.x

Weisberg, R. W. (2006). Expertise and reasoning in creative thinking: Evidence from case studies and the laboratory. In J. C. Kaufman \& J. Baer (Eds.), Creativity and reason in cognitive development (pp. 7-42). New York, NY: Cambridge University Press.

Wright, I. (2002). Challenging students with the tools of critical thinking. Social Studies, 93(6), 
$257-261$.

Yildirim, B., \& Özsoy, S. (2011). Nursing student the critical thinking development of the critical thinking education. Healthmed, 5(4), 846-856.

Young Ju, L., Bain, S. K., \& McCallum, R. (2007). Improving creative problem-solving in a sample of third culture kids. School Psychology International, 28(4), 449-463. doi:10.1177/0143034307084135 